日本臨床麻酔学会第 39 回大会シンポジウム 日臨麻会誌 Vol.40 No.3, $264 \sim 269,2020$

周術期管理は手術侵襲による合併症をどこまで軽減できるのか

手術侵襲がもたらす侵害受容と術後合併症

廣瀬宗孝*

[要旨］手術侵襲による侵害受容刺激は脊髄から大脳に伝わり侵害受容をきたすが, 同時に自律神 経反応や体動をきたす．また手術侵襲は炎症反応や組織の損傷をきたし，血中C反応性蛋白質 (CRP)濃度を増加させるが, 術後早期 CRP值は重篤な術後合併症の発症と関連がある. 一方, 侵 害受容を抑制する全身麻酔中の侵害受容のモニターは, 自律神経反応や脳波の変化を用いて侵害受 容の強さと抑制のバランスを数值化しているが，この術中の侵害受容モニター值は，手術侵襲の客 観的指標となる可能性がある.

キーワード : 手術, 術後合併症, 侵害受容, 侵害受容刺激反応, 麻酔

\section{I＼cjkstart全身麻酔は侵害受容をどこまで抑えるのか}

侵害受容刺激 (nociceptive stimulation) は体性感 覚神経にある侵害受容器(nociceptor)を刺激し，そ の刺激は脊髄，脳幹を介して大脳皮質に伝わる。こ れを侵害受容(nociception) という(図1)。全身麻酔 は侵害受容が大脳皮質まで伝わるのを抑制し, 患者 は無意識状態なので痛みを感じることもない。しか し侵害受容刺激は，脊䯣や脳幹部の自律神経反射や 運動をきたす部位は活性化させるため, 手術侵襲に よる侵害受容刺激は全身麻酔下でも心拍数や血圧の 上昇および体動などの侵害受容刺激反応をきたす。 この侵害受容刺激反応は, 侵害受容刺激の強さと全 身麻酔による侵害受容の抑制とのバランスで決まる と考えられている ${ }^{1}$.

最近のfMRI(functional MRI) による研究では, 高濃度のプロポフォールやレミフェンタニルを用い ても, 強力な侵害受容刺激は大脳皮質まで届く可能
性が示唆されている ${ }^{2), 31}$ 。ただし侵害受容刺激が大 脳皮質に伝わることと意識が生じるメカニズムは異 なるので, 全身麻酔下の手術では, 強力な侵害受容 刺激でも患者は痛みを感じることはないと考えられ ている。一方，区域麻酔は局所麻酔薬が作用する部 位より中枢に侵害受容が伝わるのを妨げるため，手 術侵襲による自律神経反応や体動をきたさない.

\section{II＼cjkstart手術侵襲で自律神経反応が生じるメカニズム}

ヒトの全身麻酔下での手術侵襲による交感神経活 動の増加は, Mashimo らが1997年に報告している ${ }^{4)}$. この反応は体性-交感神経反射 (somato-sympathetic reflex)と呼ばれ，その機序は現在では次のように 考えられている。すなわち手術侵襲による侵害受容 刺激は，末梢の TRP(transient receptor potential) チャネルやPiezo2 機械受容器などのさまざまな侵 害受容器を刺激し，体性感覚神経の中の A $\delta$ 線維と C 線維を介して中枢神経系に伝わり，脳幹の吻側延 


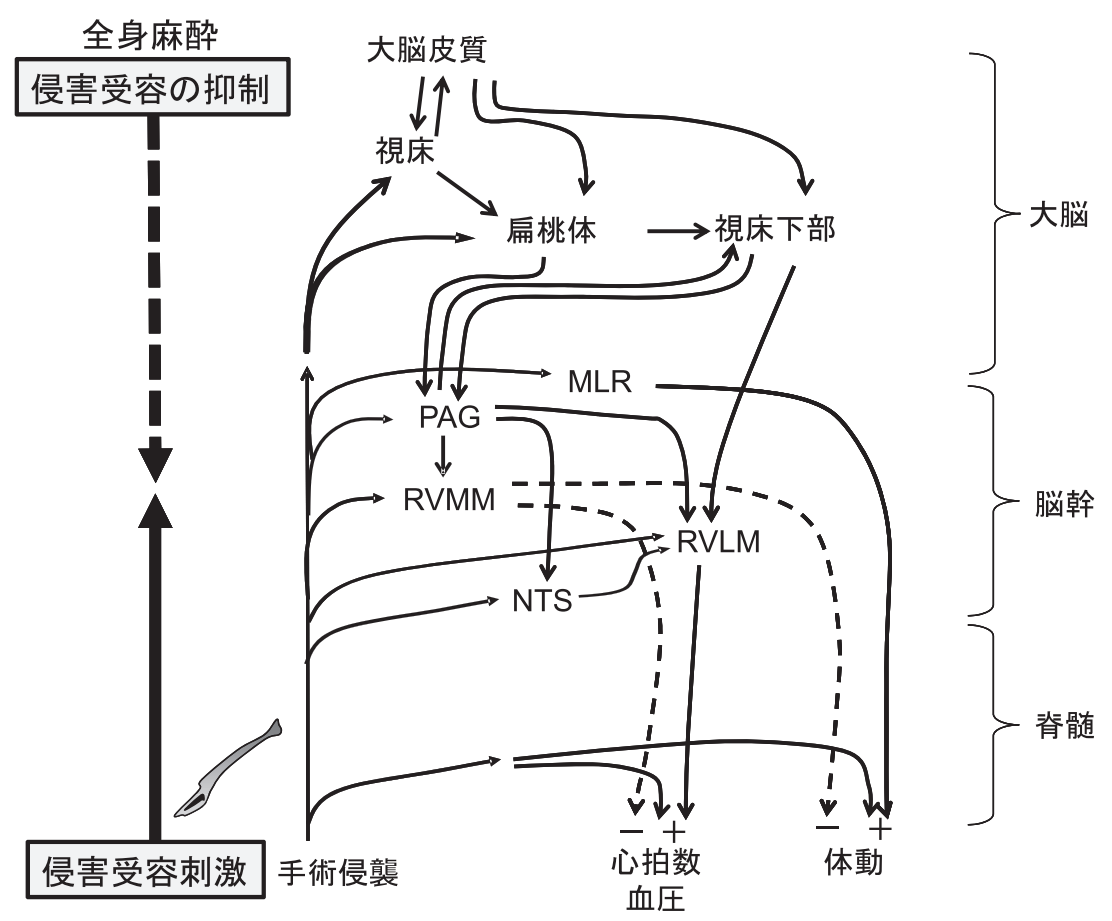

図1手術侵襲による自律神経反応

MLR : mesencephalic locomotor region(中脳歩行誘発野), NTS : nucleus tractus solitarius(孤束核), PAG : periaqueductal gray (中脳水道周囲灰白 質), RVLM : rostal ventrolateral medulla(吻側延䯣腹外側部), RVMM : rostal ventromedial medulla (吻側延髄腹内側部)

䯣腹外側部(rostal ventrolateral medulla：RVLM) を刺激することにより交感神経活動が増加する (図 1) $)^{5)}$.プロポフォール，ミダゾラム，フェンタ ニル，吸入麻酔薬などの麻酔薬は，体性一交感神経 反射を抑制することが知られている。

\section{III＼cjkstart侵害受容モニター}

手術侵襲による侵害受容刺激は，心拍数や血圧の 上昇，および末梢血流の低下や瞳孔散大などの自律 神経反応の変化や, 脳波, 筋電図の変化をきたすこと を利用して，これらの変化を変数として用いたさま ざまな侵害受容モニターが開発されている(表 1$)^{1,6)}$. ANI(analgesia nociception index)は心拍変動, SPI (surgical pleth index) は心電図のRR間隔と指先容 積脈波, NR (nociceptive response) は還流指標, 収 縮期血圧，心拍数をそれぞれ変数として数式から侵
害受容の強さを計算するものであるが，自律神経反 応の変化に影響されるため, 循環作動薬の投与で非 特異的反応をきたす欠点がある。また qNOX は脳 波を用いた侵害受容モニターであるが，鎮静薬の影 響を受ける可能性がある(表1)。

\section{IV 手術侵襲と術後合併症}

手術侵襲は侵害受容器を刺激して，末梢神経系や 中枢神経系を刺激するだけでなく，ストレス反応や 炎症反応をきたす。手術侵襲が大きくなるとこれら の反応も強くなり，さまざまな術後合併症をきたす 原因となる $(\text { 図2 })^{7)}$ 。神経系への直接の刺激は，術 後急性痛, 遷延性術後痛, 術後認知機能障害, 術後 悪心・嘔吐の原因となる。また手術ストレスの増加 や炎症反応の増加は, 臓器の血流低下，手術部位感 染，インスリン抵抗性を生じ，さらには肺炎，イレ 
表 1 侵害受容モニターの種類

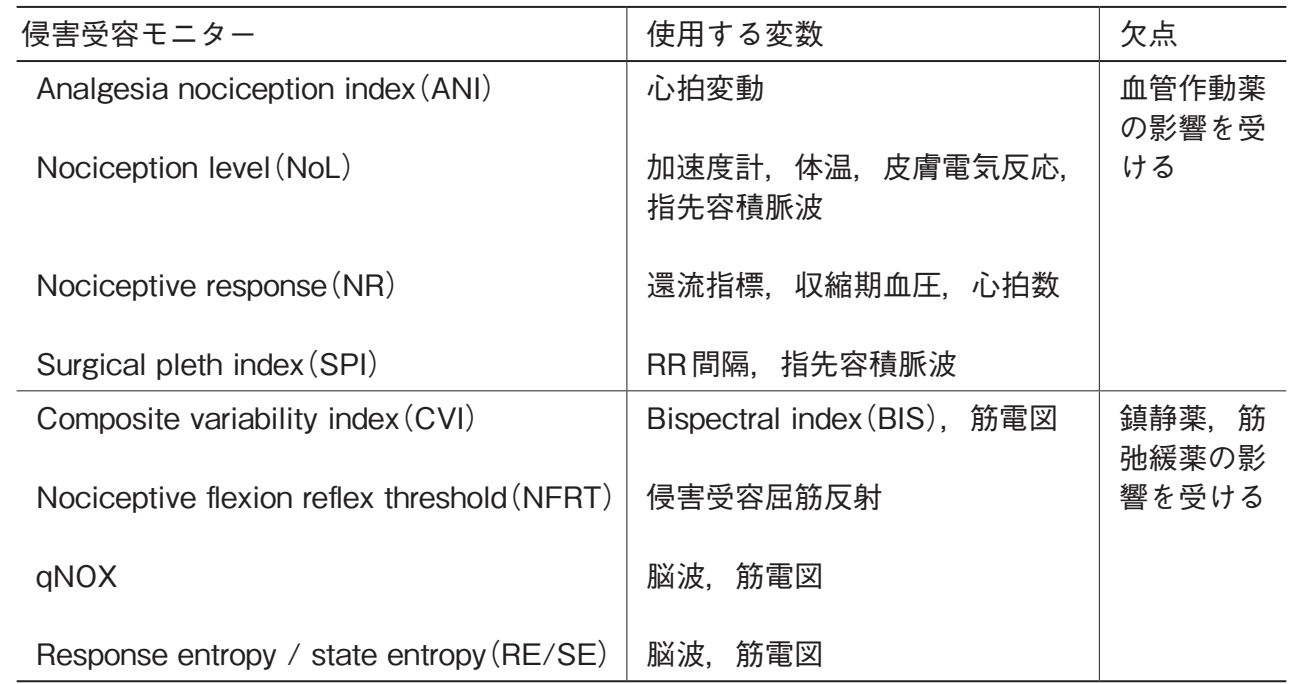

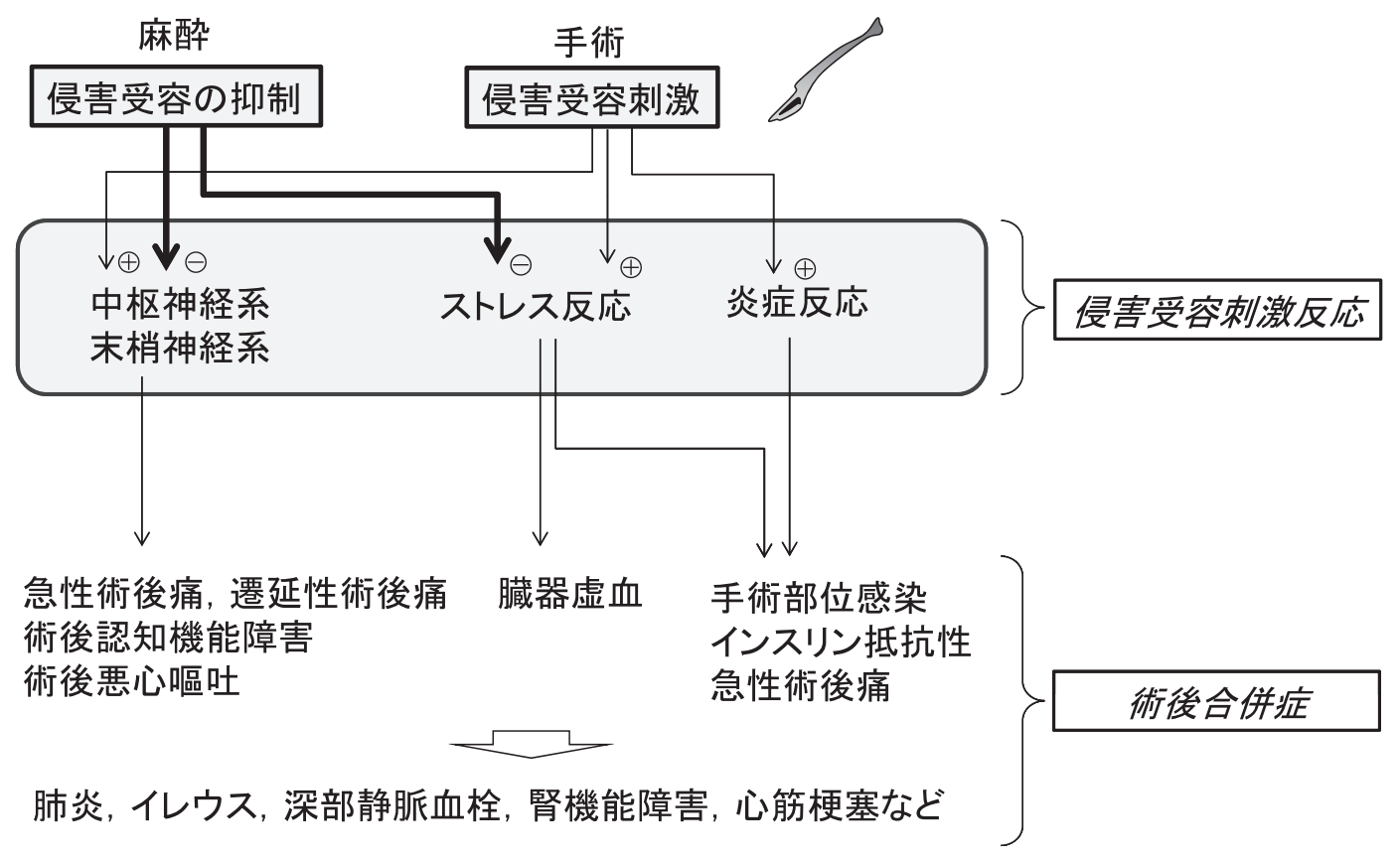

図2 手術侵襲による侵害受容刺激反応と術後合併症

ウス, 深部静脈血栓, 腎機能障害, 心筋梗塞などを きたす。手術侵襲によるこれらの合併症を抑制する ためには，神経系への影響とストレス反応と炎症反 応を抑制することが必要である7).

\section{$\mathrm{V} \quad$ 術後 CRP值を抑制する周術期管理}

C反応性蛋白質 (C-reactive protein：CRP)は，手 術侵襲による炎症反応や組織損傷に反応して肝臓で 産生され，手術後に血中濃度が増加する急性期蛋白 質の 1 つである。術後早期の血中 CRP值の増加は, 


\begin{tabular}{|c|c|}
\hline 分類 & \\
\hline Grade I & $\begin{array}{l}\text { 正常な術後経過からの逸脱で, 薬物療法, 外科的治療, } \\
\text { 内視鏡的治療, IVR治療を要さないも. }\end{array}$ \\
\hline Grade II & $\begin{array}{l}\text { 制吐剂, 解熱剂, 鎮痛剂, 利尿剂以外の薬物療法を要す } \\
\text { るもの. 輸血および中心静脈栄養を要する場合を含む。 }\end{array}$ \\
\hline Grade III & $\begin{array}{l}\text { 外科的治療, 内視鏡的治療, IVR治療を要するもの. } \\
\text { 全身麻酔を要さない治療 } \\
\text { 全身麻酔下での治療 }\end{array}$ \\
\hline Grade IV & $\begin{array}{l}\text { 集中治療管理を要するもの. } \\
\text { 生命を妿かす合併症, 単一の臓器不全 } \\
\text { 多臓器不全 }\end{array}$ \\
\hline Grade V & 死亡 \\
\hline
\end{tabular}

術後 30 日以内の術後合併症の指標である ClavienDindo 分類(表2)の Grade を増加させることが知ら れている ${ }^{8) .9)}$. 241名の大腸がん手術を受けた患者の 前向き観察研究では, 28名(12\%)がClavien-Dindo 分類の Grade III 以上の重篤な術後合併症を発症 し，その 8 割が術後感染であった ${ }^{8)}$ 。これらの患者 の術後 2〜 4 日目の血中 CRP 濃度は, Clavien-Dindo 分類が II 以下の術後合併症をきたした患者および術 後合併症をきたさなかった患者の血中 CRP 濃度よ り有意に高值であったと報告されている ${ }^{8)}$.そこで 術後早期の血中 CRP 值を抑制する周術期管理を行 えば，手術侵襲による術後合併症の発症を抑制でき る可能性がある。

Naito らは，区域麻酔は術中の手術侵襲によるス トレス反応を抑制するが，炎症反応は抑制しないこ とを報告している ${ }^{10)}$. 一方, 術後 $\mathrm{CRP}$ 值を抑制す る周術期管理として, 術前の CRP 值を抑制する術 前管理 ${ }^{11)}$ ，術中の手術侵襲を抑制するための縮小手 術 $^{12)}, \mathrm{ERAS}^{13)}$ ， ステロイド投与 ${ }^{14)}$, 非ステロイド 性消炎鎮痛薬投与 ${ }^{15)}, \beta$ ブロッカー投与 ${ }^{16)}$, リドカ イン投与 ${ }^{17)}$ が報告されている.

著者らは，非心臓手術における術後 1 日目の血中 $\mathrm{CRP}$ 值の増加は, 手術時間, 術前の CRP 值および 術中平均 NR 值から予測できることを報告した ${ }^{18)}$.
NR 值は心拍数, 収縮期血圧, 還流指標から計算す る值で，全身麻酔下の侵害受容刺激反応を評価する ことができる ${ }^{6)}$ 。このNR值の手術開始から手術終 了までの平均值である術中平均 NR 值は, 患者ごと の手術侵襲の程度を定量化できると考えている (図3)。腹腔鏡下胃腸手術を施行した158名の術前 状態の安定した患者における後向き観察研究では, Clavien-Dindo 分類がGrade IIIa 以上の重篤な術後 合併症をきたした患者は 13 名(8.2\%)で，Grade II またはGrade IIIa 以上の患者の術中平均 NR 值と手 術時間は，術後合併症がGrade I もしくは合併症な しの患者と比較して有意に高值であった ${ }^{19}$ 。 しかし 術中の NR 值を抑制する麻酔管理が術後合併症の発 症を抑制することを明らかにするためには, ランダ ム化比較試験が必要である。

本稿は日本臨床麻酔学会第 39 回大会シンポジウ ム「周術期管理は手術侵襲による合併症をどこまで 軽減できるのか」において発表した「侵害受容刺激 反応と術後合併症」の内容をまとめたものである.

\section{参考文献}

1) Ledowski $\mathrm{T}$ : Objective monitoring of nociception : a review of current commercial solutions. Br J Anaesth 


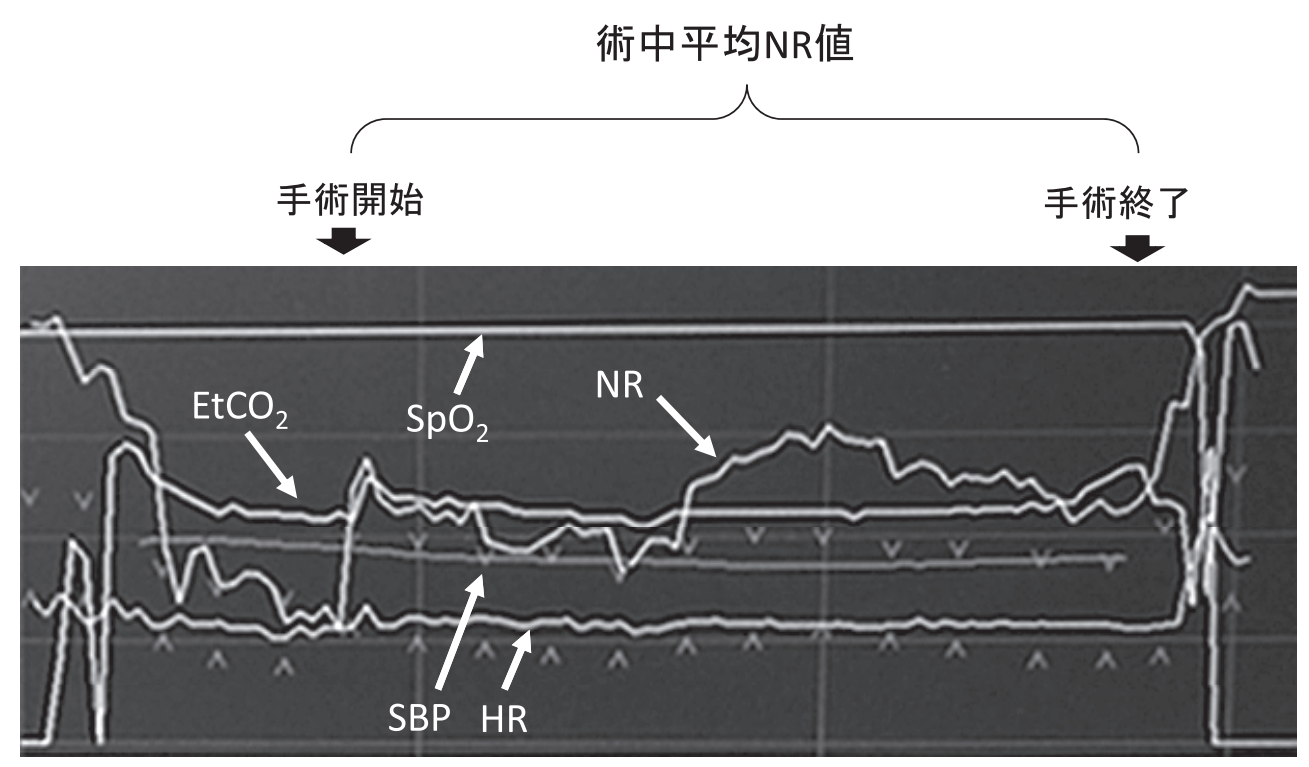

図3手術侵襲を定量化する試み

$\mathrm{EtCO}_{2}$ : end-tidal carbon dioxide, HR : heart rate, NR : nociceptive response, SBP : systolic blood pressure, $\mathrm{SpO}_{2}$ : oxygen saturation measured by pulse oximetry

123 : e312-e321, 2019

2) Lichtner G, Auksztulewicz R, Kirilina E, et al. : Effects of propofol anesthesia on the processing of noxious stimuli in the spinal cord and the brain. Neuroimage $172: 642-653,2018$

3) Lichtner G, Auksztulewicz R, Velten H, et al. : Nociceptive activation in spinal cord and brain persists during deep general anaesthesia. Br J Anaesth 121 : 291-302, 2018

4) Mashimo T, Zhang P, Kamibayashi T, et al. : Laser Doppler skin blood flow and sympathetic nervous responses to surgical incision during halothane and isoflurane anesthesia. Anesth Analg 85 : 291-298, 1997

5) Cividjian A, Petitjeans F, Liu N, et al. : Do we feel pain during anesthesia? A critical review on surgeryevoked circulatory changes and pain perception. Best Pract Res Clin Anaesthesiol 31 : 445-467, 2017

6) Hirose M, Kobayashi Y, Nakamoto S, et al. : Development of a Hemodynamic Model Using Routine Monitoring Parameters for Nociceptive Responses Evaluation During Surgery Under General Anesthesia. Med Sci Monit 24 : 3324-3331, 2018

7) Dobson GP : Addressing the global burden of trauma in major surgery. Front Surg $2: 43,2015$

8) McSorley ST, Ramanathan ML, Horgan PG, et al. : Postoperative C-reactive protein measurement predicts the severity of complications following surgery for colorectal cancer. Int J Colorectal Dis 30 : 913-917, 2015

9) Straatman J, Cuesta MA, Tuynman JB, et al. : C-reactive protein in predicting major postoperative complications are there differences in open and minimally invasive colorectal surgery? Substudy from a randomized clinical trial. Surg Endosc 32 : 2877-2885, 2018

10) Naito $Y$, Tamai S, Shingu K, et al. : Responses of plasma adrenocorticotropic hormone, cortisol, and cytokines during and after upper abdominal surgery. Anesthesiology $77:$ 426-431, 1992

11) Perry TE, Muehlschlegel JD, Liu KY, et al. : Preoperative $\mathrm{C}$-reactive protein predicts long-term mortality and hospital length of stay after primary, nonemergent coronary artery bypass grafting. Anesthesiology $112: 607-613,2010$

12) Demir A, Bige O, Saatli B, et al. : Prospective comparison of tissue trauma after laparoscopic hysterectomy types with retroperitoneal lateral transsection of uterine vessels using ligasure and abdominal hysterectomy. Arch Gynecol Obstet 277 : 325-330, 2008

13) Mari G, Costanzi A, Crippa J, et al. : Surgical Stress Reduction in Elderly Patients Undergoing Elective Colorectal Laparoscopic Surgery within an ERAS Protocol. Chirurgia(Bucur) $111:$ 476-480, 2016

14) Maruta K, Aoki A, Omoto T, et al. : The Effect of Steroid Therapy on Postoperative Inflammatory Response 
after Endovascular Abdominal Aortic Aneurysm Repair. Ann Vasc Dis $9:$ 168-172, 2016

15) Kuchálik J, Magnuson A, Tina E, et al. : Does local infiltration analgesia reduce peri-operative inflammation following total hip arthroplasty? A randomized, double-blind study. BMC Anesthesiol $17: 63,2017$

16) Kim Y, Hwang W, Cho ML, et al. : The effects of intraoperative esmolol administration on perioperative inflammatory responses in patients undergoing laparoscopic gastrectomy : a dose-response study. Surg Innov $22: 177-182,2015$

17) Choi GJ, Kang H, Ahn EJ, et al. : Clinical Efficacy of
Intravenous Lidocaine for Thyroidectomy: A Prospective, Randomized, Double-Blind, Placebo-Controlled Trial. World J Surg 40 : 2941-2947, 2016

18) Nakamoto S, Hirose M : Prediction of early C-reactive protein levels after non-cardiac surgery under general anesthesia. PLoS One 14 : e0226032, 2019

19) Ogata H, Nakamoto S, Miyawaki H, et al. : Association between intraoperative nociception and postoperative complications in patients undergoing laparoscopic gastrointestinal surgery. J Clin Monit Comput, 2019 ; doi : 10.1007/s10877-019-00347-3 [Epub ahead of print]

\title{
Surgical Invasion Evoking Nociception and Postoperative Complications
}

\author{
Munetaka HIROSE \\ Department of Anesthesiology and Pain Medicine, Hyogo College of Medicine
}

Surgical invasion induces nociceptive stimuli, in which signals ascend from the spinal cord to the cerebral cortex, evoking nociception. It simultaneously causes autonomic responses and body movement. Surgical invasion also causes inflammatory responses and tissue damage during and after surgery, increasing C-reactive protein (CRP) levels in blood. Early increases in postoperative CRP levels are associated with severe postoperative complications. On the other hand, general anesthesia suppresses nociception. Nociception monitoring under general anesthesia estimates a quantified balance between nociception and anti-nociception by using variables evoked by autonomic responses or in the electroencephalogram. A nociception monitoring value during surgery has the potential to be an objective indicator of surgical invasion.

Key Words : Anesthesia, Nociception, Nociceptive response, Postoperative complications, Surgery

The Journal of Japan Society for Clinical Anesthesia Vol.40 No.3, 2020 